\title{
Isolated sacral agenesis in a fetus monosomic for $7 \mathrm{q} 36.1 \rightarrow \mathrm{qter}$
}

\author{
N M Savage, N A Maclachlan, C A Joyce, I E Moore, J A Crolla
}

\begin{abstract}
A fetus with severe sacral agenesis and intrauterine growth retardation, ascertained at prenatal diagnosis, was found to be carrying an unbalanced form of a paternal balanced reciprocal translocation (7;19)(q36.1;q13.43), resulting in functional monosomy for $7 q 36.1 \rightarrow$ qter. Necropsy confirmed that the fetus had isolated sacral agenesis type II. A critical region for autosomal dominant sacral agenesis has recently been mapped to the 7 q36 region. This case provides further evidence for a sacral agenesis locus in this region and may help to refine the critical region further.

$(\Im$ Med Genet 1997;34:866-868)
\end{abstract}

Keywords: sacral agenesis; 7q36

Sacral agenesis is a rare, usually sporadic disorder in which there is failure of development at the caudal end of the neural tube, resulting in aplastic malformations of the sacral vertebrae. ${ }^{1}$ Sporadic sacral agenesis is most commonly associated with maternal diabetes, ${ }^{23}$ and the rarer, hereditary form may occur in isolation or as part of the Currarino triad of anorectal, sacral, and presacral anomalies. ${ }^{4}$ The association of terminal $7 q$ deletions with developmental anomalies of both the sacral region and the prosencephalon has been well documented. ${ }^{56}$ A critical region for holoprosencephaly (HPE), an early malformation of the rostral end of the neural tube resulting in structural anomalies of the forebrain and midface, maps to chromosomal region $7 q 36,{ }^{7}$ and a gene for autosomal dominant sacral agenesis has recently been reported to map to the same region.

\section{Case report}

A 29 year old Portuguese woman, G1, P0, was referred for amniocentesis at 16 weeks' gestation because of a raised maternal serum alphafetoprotein. Ultrasound studies detected intrauterine growth retardation and a possible sacral anomaly. On the basis of the cytogenetic result (see below) the pregnancy was terminated, and necropsy showed a female fetus with features of intrauterine growth retardation and severe sacral hypoplasia (sacral agenesis type II) (fig 1), but no internal congenital abnor-
Wessex Regional Genetics Laboratory, Salisbury District Hospital, Salisbury, Wiltshire SP2 8BJ, UK N M Savage

C A Joyce

J A Crolla

Jersey Maternity Hospital, St Helier, Jersey, Channel Islands N A Maclachlan

Southampton General Hospital, Tremona Road, Southampton, Hants SO16 6YD, UK I E Moore

Correspondence to: N M Savage.

Received 1 November 1996 Revised version accepted for publication 17 April 1997

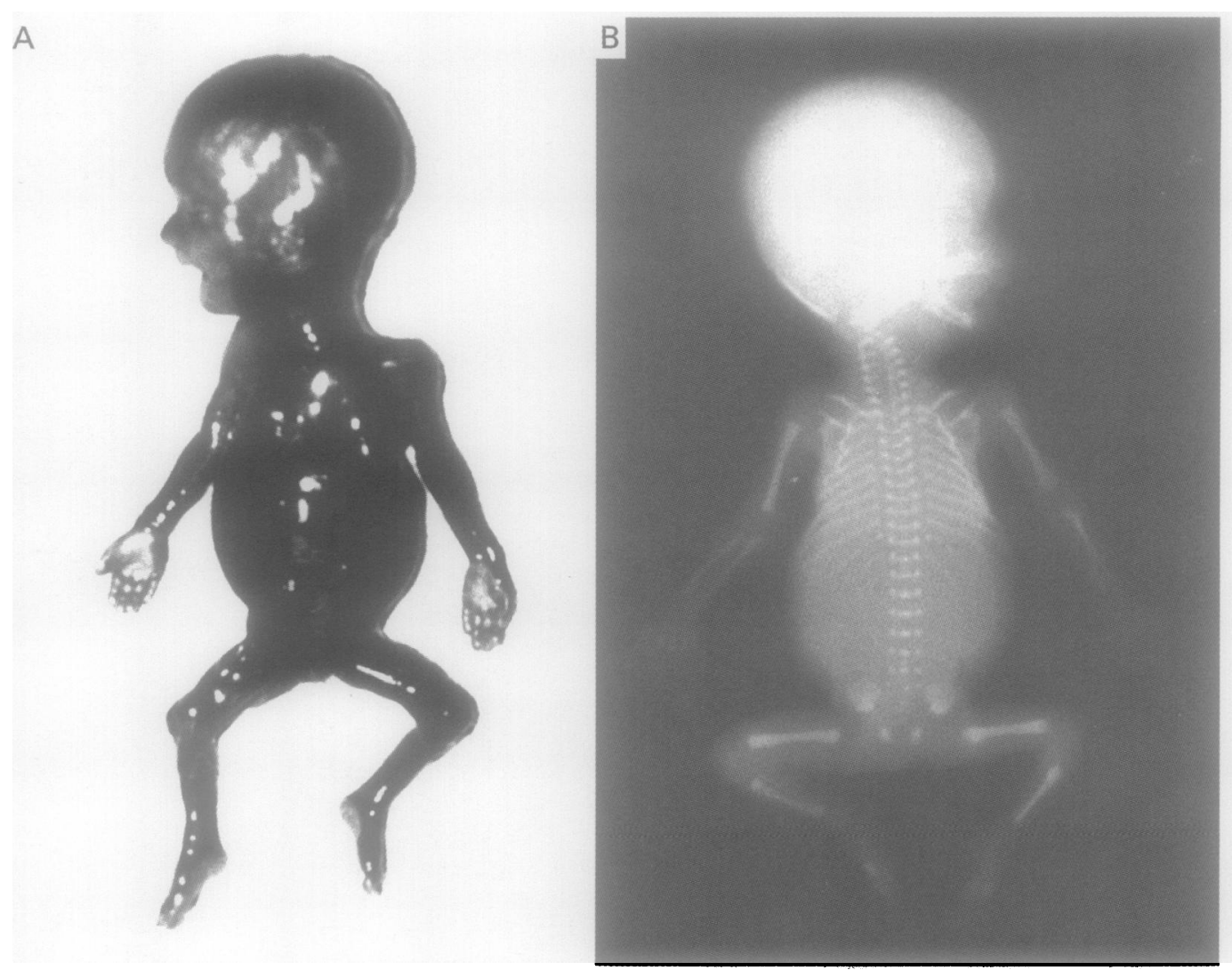

Figure 1 (A) Clinical appearance of the fetus. (B) Radiograph showing failure of development of the sacral vertebrae. 


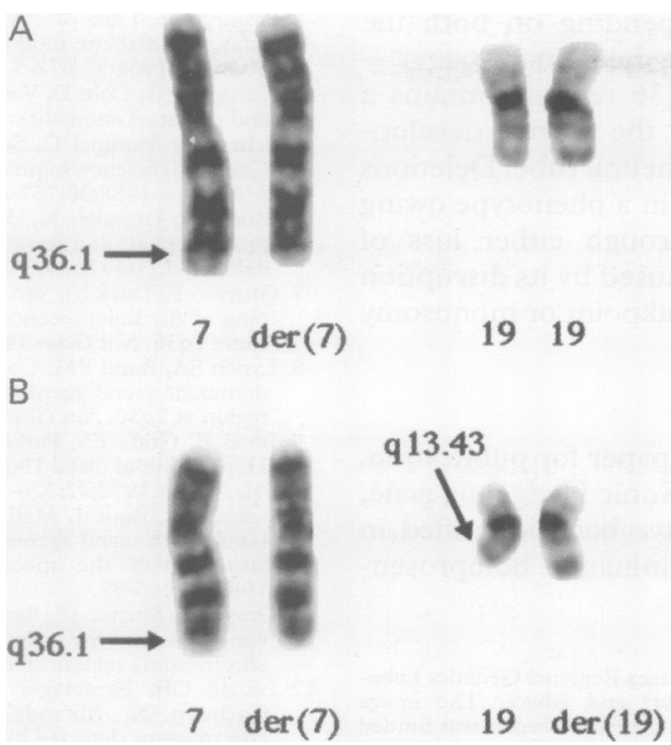

Figure 2 Partial $G$ banded karyotypes of $(A)$ the fetus and $(B)$ the father. Arrows indicate the breakpoints.

malities. The placenta showed extensive areas of infarction. There was no consanguinity and the mother was not diabetic.

\section{Cytogenetic and FISH studies}

All cells examined from cultured amniocytes had an apparent small terminal deletion of one chromosome 7 which, on examination of the parental karyotypes, was shown to be the unbalanced product of a balanced 7;19 translocation (fig 2). Examination of fetal fibroblasts confirmed the amniocentesis result. Fluorescence in situ hybridisation using the Oncor Williams Syndrome Chromosome Region (WSCR) probe, which maps within 7q11.23 and includes a control probe D7S427 that hybridises to 7q36, confirmed both the unbalanced and balanced karyotypes (fig 3 ). The father's karyotype was $46, \mathrm{XY}, \mathrm{t}(7 ; 19)$ (q36.1; $q 13.43)$.ish $t(7 ; 19)(D 7 S 427-; D 7 S 427+)$, the fetal karyotype therefore being 46,XX,der (7) $t(7 ; 19)(q 36.1 ; q 13.43)$.ish $\operatorname{der}(7) t(7 ; 19)$ (D7S427-)pat.

\section{Discussion}

Adjacent 1 segregation of the balanced paternal $7 ; 19$ translocation had given rise to a fetus which was trisomic for a small portion of distal $19 q(q 13.43 \rightarrow q t e r)$ and monosomic for the subtelomeric region of $7 \mathrm{q}(\mathrm{q} 36.1 \rightarrow \mathrm{qter})$. Duplications of distal 19q have been reviewed by Boyd et al, ${ }^{9}$ but none of the clinical features described in the review was present in our case, presumably because the duplicated regions in the reviewed cases were more extensive than in the present case. By contrast, the association between terminal $7 \mathrm{q}$ deletions and developmental anomalies of the prosencephalon and the caudal region is well known and has been reviewed by Morichon-Delvallez et al. ${ }^{6}$ Three of the 13 cases described in that paper showed coexistence of HPE and sacral agenesis. Lynch et $a l^{\beta}$ suggested that the genes for HPE and sacral agenesis are allelic, and involvement of different functional domains of the gene could explain the occurrence of one or other of the phenotypes. The phenotypic features of HPE and sacral agenesis are variable, with features of HPE ranging from midface hypoplasia to cyclopia, ${ }^{7}$ and those of sacral agenesis from partial agenesis of the coccyx to complete absence of the sacral and lumbar vertebrae. ${ }^{1}$ Lynch $e t a l^{\beta}$ proposed that this variable expression, and early miscarriage particularly involving the more severe phenotypes, may obscure the true frequency of the coexistence of the two defects. Sacral agenesis has also been reported in combination with spina bifida, a classical neural tube defect. ${ }^{10}$

Grass et $a l,{ }^{11}$ in an abstract, described three cases with deletions of distal $7 q$ with variable phenotypes. Case 1 , monosomic for 7q34 $\rightarrow$ qter, showed no evidence of HPE; case 2, hemizygous for the D7S427 probe in 7q36, had a single central incisor, a feature seen in the mildest expression of HPE; and case 3, monosomic for $7 \mathrm{q} 36 \rightarrow \mathrm{qter}$, had HPE which was detected prenatally by ultrasound. These variable HPE phenotypes, together with the coexistence of sacral agenesis, HPE, and spina bifida, and cases of isolated sacral agenesis (our case and that of Lozzio et $a l^{12}$ ) could be explained if the genes were not allelic, as proposed by Lynch et al, ${ }^{8}$ but rather contiguous, with deletions in specific loci giving rise to

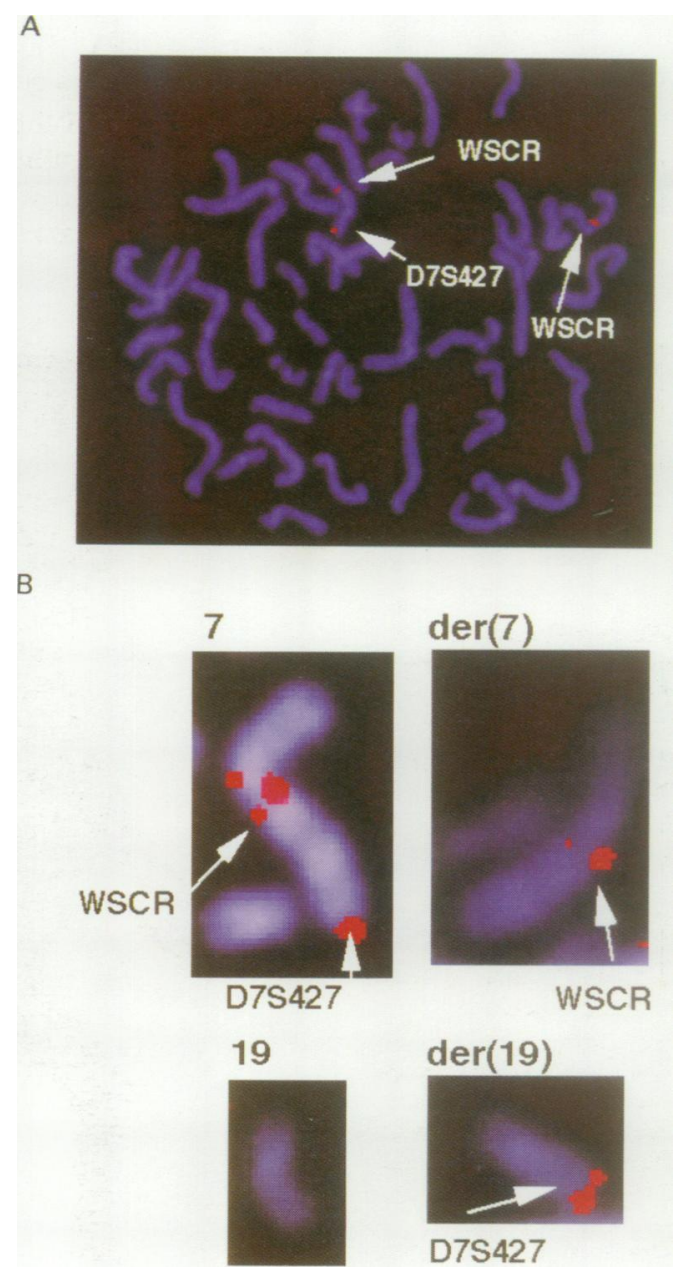

Figure 3 FISH with the WSCR probe. (A) Metaphase from the fetus showing only one D7S427 signal. (B) Chromosomes 7 and 19 from the father showing a D7S427 signal present on distal 19q. 
different phenotypes depending on both the position and extent of the deletion.

It appears that the $7 \mathrm{q} 36$ region contains a gene or genes crucial for the normal development of both ends of the neural tube. Deletions of this region may result in a phenotype owing to haploinsufficiency through either loss of function of the gene(s) caused by its disruption at the rearrangement breakpoint or monosomy for the gene(s) involved.

\section{Addendum}

Since submission of this paper for publication, mutations in the human Sonic Hedgehog gene, which maps to $7 q 36$, have been identified in several autosomal dominant holoprosencephaly families. ${ }^{13} 14$

We thank our colleagues at the Wessex Regional Genetics Laboratory for their technical support and advice. The image enhancement equipment used for the FISH studies was funded by the Wellcome Trust.

1 Pang D. Sacral agenesis and caudal spinal cord malformations. Neurosurgery 1993;32:755-79.

2 Kalter $H$. Case reports of malformations associated with maternal diabetes: history and critique. Clin Genet 1993;43:174-9.
3 Passarge E, Lenz W. Syndrome of caudal regression in infants of diabetic mothers: observations of further cases. Pediatrics 1966;37:672-5.

4 Currarino G, Coln D, Votteler T. Triad of anorectal, sacral, and presacral anomalies. $A \mathcal{F}$ 1981;137:395-8.

5 Schrander-Stumpel C, Schrander J, Fryns JP, Hamers G. Caudal deficiency sequence in $7 \mathrm{q}$ terminal deletion. $A m \mathcal{F}$ Med Genet 1988;30:757-61.

6 Morichon-Delvallez N, Delezoide AL, Vekemans M. Holoprosencephaly and sacral agenesis in a fetus with a terminal prosencephaly and sacral agenesis in a fetus with a
deletion $7 q 36 \rightarrow 7 q$ ter. $₹$ Med Genet 1993;30:521-4.

7 Gurrieri F, Trask BJ, Van Den Engh G, et al. Physical mapping of the holoprosencephaly critical region on chromosome 7q36. Nat Genet 1993;3:247-51.

8 Lynch SA, Bond PM, Copp AJ, et al. A gene for autosomal dominant sacral agenesis maps to the holoprosencephaly region at 7q36. Nat Genet 1995;11:93-6.

9 Boyd E, Grass FS, Parke JC, Knutson K, Stevenson RE. Duplication of distal $19 \mathrm{q}$ - clinical report and review. $A m \mathcal{F}$ Med Genet 1992;42:326-30.

10 Fellous M, Boue J, Malbrunot C, et al. A five-generation family with sacral agenesis and spina bifida: possible similamities with the mouse T-locus. Am $f$ Med Genet larities with the

11 Grass FS, Spence JE, Saikevych IA, et al. 7q deletions and variations in the expression of a holoprosencephaly chromosome region. Am $\mathcal{F}$ Hum Genet 1995;57:A114.

12 Lozzio CB, Bamberger E, Worthington C, Holland E, Cacheiro N. Microdeletion $7 \mathrm{q} 36$ in a recombinant chromosome detected by FISH. Am $\mathcal{F}$ Hum Genet 1995;57: A119.

13 Belloni E, Muenke M, Roessler E, et al. Identification of Sonic Hedgehog as a candidate gene responsible for Sonic Hedgehog as a candidate gene respon

14 Roessler E, Belloni E, Gaudenz K, et al. Mutations in the human Sonic Hedgehog gene cause holoprosencephaly. Nat Genet 1996;14:357-60. 